\title{
PEMBENAHAN HALAMAN KANTOR KELURAHAN BONTOTANGNGA
}

\section{(KELURAHAN BONTOTANGNGA KEC.TAMALATEA)}

NAMA : ANNISA HASAN

NIM : 9173490210030

EMAIL : annisahasan3011@gmail.com

1. Bentuk Kegiatan

- Pembenahan halaman Kantor Lurah Bontotangnga

2. Lokasi

- Kantor Lurah Bontotangnga Kec.Tamalatea

3. Hari Tanggal Dan Waktu

- Hari Kamis, Tanggal 22 Oktober 2020 Pukul 10.00 Wita

4. Peserta Yang Dilibatkan

- Mahasiswa KKLP YAPTI JENEPONTO

5. Alasan Yang Diadakannya

- Setelah Observasi lapangan, kami melihat pekarangan di kantor tersebut sangatlah gersang maka dari itu kami berinisiatif untuk mengadakan program kera ini.

6. Tujuan Dan Manfaat

- Kami mengadakan program kerja ini agar pekarangan Kantor Lurah Bontotangnga jauh lebih asri dari yang sebelumnya.

7. Deskripsi kegiatan

- Proses pembenahan halaman kantor lurah ini dilakukan selama beberapa hari. Pembenahan ini dilakukan agar halaman kantor lurah jauh lebih asri dari yang sebelumnya. 